\title{
Other micro-particles: Volcanic glass, minerals, insect remains, feathers, and other plant parts
}

\author{
Amanda G. Henry \\ HARVEST project, Faculty of Archaeology, Leiden University, Einsteinweg 2, 2333CC Leiden, \\ The Netherlands \\ a.g.henry@arch.leidenuniv.nl
}

\section{Abstract}

While this book has introduced the most abundant and potentially informative microparticles that will be found in archaeological contexts, there are a few that have not yet been discussed. This chapter includes brief descriptions and pictures of some of the other micro-particles that the reader may come across.

\section{Keywords}

Volcanic glass; tephra; mineral particles; feather barbules; insect parts; fern sporangia; raphides

\section{Volcanic glass}

Microscopic particles of volcanic glass, called tephra, are occasionally found in archaeological sediments. Tephra can be correlated to volcanic eruptions of known ages, based on morphology and on chemical signatures, and can thus provide a means of dating an archaeological layer. Tephra particles may be identified based on their color, shape, isotropy and size and shape of their gas inclusions (also called vesicules). They are generally glassy, and can range from clear to uneven translucent brown (Fig. 12.1). They can appear as irregularly broken shards of glass, but can also be flat/platy, or with abundant linear gas inclusions (sometimes called pulled or fluted), or with many small bubbles (sometimes called bubbly or vesicular) (Stevenson et al., 2015; Swindles et al., 2010). Because they are isotropic, tephra do not glow under cross-polarized light. This feature may help differentiate them from other minerals. Once identified using light microscopy, the tephra are usually further analyzed using a variety of methods to determine the relative proportions of minerals that provide the unique fingerprint for each volcanic eruption (Swindles et al., 2010). 


\section{Mineral particles}

In rare cases, visually identifiable mineral particles have been recovered from dental calculus samples. The notable example was the identification of blue particles seen in a preparation of calculus from a $10^{\text {th }}$ century German woman who lived in a religious community (Radini et al., 2019). The particles were first viewed in the calculus during a preparation for plant microremains analysis, and subsequently confirmed as coming from lapis lazuli using scanning electron microscopy with energy-dispersive x-ray spectroscopy and micro-Raman spectroscopy.

\section{Insect remains}

Insect remains are common on archaeological materials. Larger body parts such as heads, thoraxes, wings, legs, and mandibles often retain morphology which allows the identification of taxa. Some insects have known preferred habitats, foods, and temperature ranges, and have been used for environmental reconstruction [e.g., insect remains helped establish the lack of cold temperatures of a late glacial deposit in the Netherlands (Van Geel et al., 1989)] . Similarly, the presence or absence of insect parts in human occupations provides information about past behaviors, particularly about animal husbandry, fur and leather use, and hygiene [e.g., the spatial patterning of human- and dog-lice remains in Inuit homes in Greenland reflected where dogs were allowed and where human parasites were removed (Forbes et al., 2013)]. Not all insect parts can be so successfully used for reconstructing past behavior or environments, however. In the author's laboratory, other microscopic parts of insects, namely hairs from the larvae of dermestid beetles (Fig. $12.2 \mathrm{a}-\mathrm{c}$ ), and the wing scales from moths or butterflies (Fig $12.2 \mathrm{~d} \& \mathrm{e}$ ) have been recovered from a variety of sample types, including calculus, stone tools, and controls. These taxa are common pests of museum collections (Querner, 2015) and therefore likely indicate post-excavation contamination.

\section{Feather barbules}

Fragments of bird feathers can occasionally be found in archaeological samples. These feather barbules vary in length (though complete barbules are rare in archaeological samples), node morphology, internode length, pigment location and distribution, and surface texture (Fig. 12.3), and can in some cases be identified to the bird taxa that produced them (Dove and Koch, 2011). The barbules are made of keratin, and thus of moderate survivability in the archaeological record (Bertrand et al., 2014). Barbules have been recovered from fabrics (Sibley et al., 1992), stone tools (Robertson, 2002; Robertson et al., 2009), and dental calculus (Gismondi et al., 2018; Juhola et al., accepted/in press).

\section{Other plant markers}

In addition to charcoal, ash pseudomorphs, pollen, phytoliths, and starch, other plant remains may also be preserved in the archaeological record, and have the potential to provide information about environment and behavior. 
As part of their reproductive system, ferns produce sporangia on the underside of their leaves. Sporangia have been recovered in sediments (author, unpublished data, Fig. 12.4), and dental calculus (Fiorin et al., 2019). These large, often colorful objects, or fragments of the distinct, radially-grooved margin (called the annulus) can be identified to fern taxa and may therefore provide information about dietary or medicinal use of these plants.

Many plants deposit calcium oxalate in their tissues, often in the form of needle-like raphides, in addition to druses and rhombs (see Chapter 6 by Gur-Arieh and Shahack-Gross, this volume). These raphides are produced as a means of defense against herbivory, as their shape irritates the mouths and throats of consumers (Bradbury and Nixon, 1998). They are particularly abundant in the Araceae (Crowther, 2009a), but are also found in Oxalidaceae and in other potentially archaeologically-relevant taxa such as Vitis (grapes) (Arnott and Webb, 2000). Raphides can form singly or in bundles, and can have distinctive morphology (e.g., varying shapes of the points, barbs, cross-sections, or crystal structures) (Fig. 12.5) depending on the plant in which they formed (Crowther, 2009a). When recovered from stone tools and other samples, raphides can help identify the use of particular plants (e.g., Horrocks and Bedford, 2005). However, calcium oxalate is not always preserved in archaeological contexts (see Chapter 6), and raphide-like needle-fiber calcite crystals form readily on archaeological materials (Crowther, 2009b), so care must be taken when interpreting these objects. Good identification relies on a deep and broad reference collection of raphides, the use of SEM in addition to light microscopy, and potentially chemical tests that would dissolve calcite while leaving calcium oxalate unharmed (Crowther, 2009b, 2009a).

Other plant remains such as xylem vessel elements and leaf epidermal tissues have been reported in studies of coprolites and sediments (e.g., Horrocks et al., 2008; Horrocks and Lawlor, 2006). Further research into these less-common plant remains is needed. 


\section{References}

Arnott, H.J., Webb, M.A., 2000. Twinned Raphides of Calcium Oxalate in Grape (Vitis): Implications for Crystal Stability and Function. International Journal of Plant Sciences 161, 133-142. https://doi.org/10.1086/314230

Bertrand, L., Vichi, A., Doucet, J., Walter, P., Blanchard, P., 2014. The fate of archaeological keratin fibres in a temperate burial context: microtaphonomy study of hairs from Marie de Bretagne (15th c., Orléans, France). Journal of Archaeological Science 42, 487-499. https://doi.org/10.1016/j.jas.2013.11.028

Bradbury, J.H., Nixon, R.W., 1998. The acridity of raphides from the edible aroids. Journal of the Science of Food and Agriculture 76, 608-616. https://doi.org/10.1002/(SICI)10970010(199804)76:4<608::AID-JSFA996>3.0.CO;2-2

Crowther, A., 2009a. Morphometric analysis of calcium oxalate raphides and assessment of their taxonomic value for archaeological microfossil studies, in: Haslam, M., Robertson, G., Crowther, A., Nugent, S., Kirkwood, L. (Eds.), Archaeological Science Under a Microscope: Studies in Residue and Ancient DNA Analysis in Honour of Thomas H. Loy. ANU Press, pp. 102-128.

Crowther, A., 2009b. Re-viewing raphides: Issues with the identification and interpretation of calcium oxalate crystals in microfossil assemblages, in: Fairbairn, A.S., O’Connor, S., Marwick, B. (Eds.), New Directions in Archaeological Science. ANU E Press, Canberra, pp. 105-118.

Dove, C.J., Koch, S.L., 2011. Microscopy of Feathers: A Practical Guide for Forensic Feather Identification. The MIcroscope 59, 51-71.

Fiorin, E., Sáez, L., Malgosa, A., 2019. Ferns as healing plants in medieval Mallorca, Spain? Evidence from human dental calculus. International Journal of Osteoarchaeology 29, 82-90. https://doi.org/10.1002/oa.2718

Forbes, V., Dussault, F., Bain, A., 2013. Contributions of ectoparasite studies in archaeology with two examples from the North Atlantic region. International Journal of Paleopathology 3, 158-164. https://doi.org/10.1016/j.ijpp.2013.07.004

Gismondi, A., D’Agostino, A., Canuti, L., Di Marco, G., Martínez-Labarga, C., Angle, M., Rickards, O., Canini, A., 2018. Dental calculus reveals diet habits and medicinal plant use in the Early Medieval Italian population of Colonna. Journal of Archaeological Science: Reports 20, 556-564. https://doi.org/10.1016/j.jasrep.2018.05.023

Horrocks, M., Bedford, S., 2005. Microfossil analysis of Lapita deposits in Vanuatu reveals introduced Araceae (aroids). Archaeology in Oceania 40, 67-74. https://doi.org/10.1002/j.1834-4453.2005.tb00587.x

Horrocks, M., Lawlor, I., 2006. Plant microfossil analysis of soils from Polynesian stonefields in South Auckland, New Zealand. Journal of Archaeological Science 33, 200-217. https://doi.org/10.1016/j.jas.2005.07.014

Horrocks, M., Salter, J., Braggins, J., Nichol, S., Moorhouse, R., Elliott, G., 2008. Plant microfossil analysis of coprolites of the critically endangered kakapo (Strigops habroptilus) parrot from New Zealand. Review of Palaeobotany and Palynology 149, 229-245.

https://doi.org/10.1016/j.revpalbo.2007.12.009 
Juhola, T.S., Henry, A.G., Kirkinen, T., Laakkonen, J., Väliranta, M., accepted/in press. Phytoliths, parasites, fibers and feathers from dental calculus and soil from Iron Age Luistari cemetery, Finland. Quaternary Science Reviews.

Querner, P., 2015. Insect Pests and Integrated Pest Management in Museums, Libraries and Historic Buildings. Insects 6, 595-607. https://doi.org/10.3390/insects6020595

Radini, A., Tromp, M., Beach, A., Tong, E., Speller, C., McCormick, M., Dudgeon, J.V., Collins, M.J., Rühli, F., Kröger, R., Warinner, C., 2019. Medieval women’s early involvement in manuscript production suggested by lapis lazuli identification in dental calculus. Science Advances 5, eaau7126. https://doi.org/10.1126/sciadv.aau7126

Robertson, G., 2002. Birds of a feather stick: Microscopic feather residues on stone artefacts from Deep Creek Shelter, New South Wales. Tempus 7, 175-182.

Robertson, G., Attenbrow, V., Hiscock, P., 2009. Multiple uses for Australian backed artefacts. Antiquity 83, 296-308.

Sibley, L.R., Jakes, K.A., Swinker, M.E., 1992. Etowah Feather Remains from Burial 57: Identification and Context. Clothing and Textiles Research Journal 10, 21-28. https://doi.org/10.1177/0887302X9201000304

Stevenson, J., Millington, S., Beckett, F., Swindles, G., Thordarson, T., 2015. Big grains go far: Understanding the discrepancy between tephrochronology and satellite infrared measurements of volcanic ash. Atmospheric Measurement Techniques 8, 2069-2091. https:// doi.org/10.5194/amt-8-2069-2015

Swindles, G., Vleeschouwer, F., Plunkett, G., 2010. Dating peat profiles using tephra: stratigraphy, geochemistry and chronology. Mires and Peat 7.

Van Geel, B., Coope, G.R., Van Der Hammen, T., 1989. Palaeoecology and stratigraphy of the lateglacial type section at Usselo (the Netherlands). Review of Palaeobotany and Palynology 60, 25-129. https://doi.org/10.1016/0034-6667(89)90072-9 


\section{Figure captions}

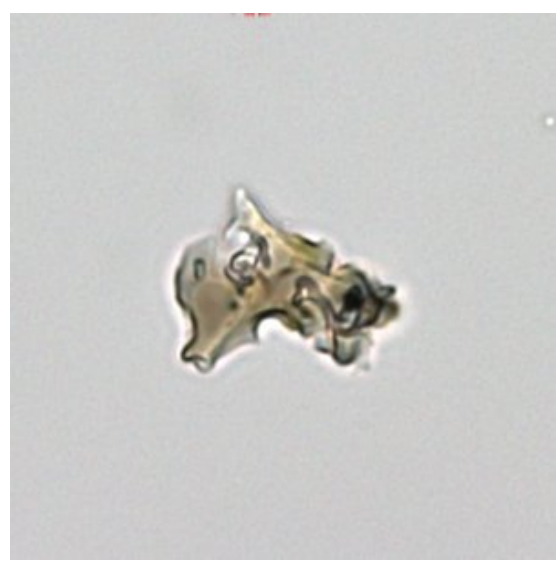

Figure 12.1: An example tephra particle, of the light brown 'bubbly' type. This particle was recovered from faunal dental calculus. The box is $50 \mu \mathrm{m}$ on a side. 

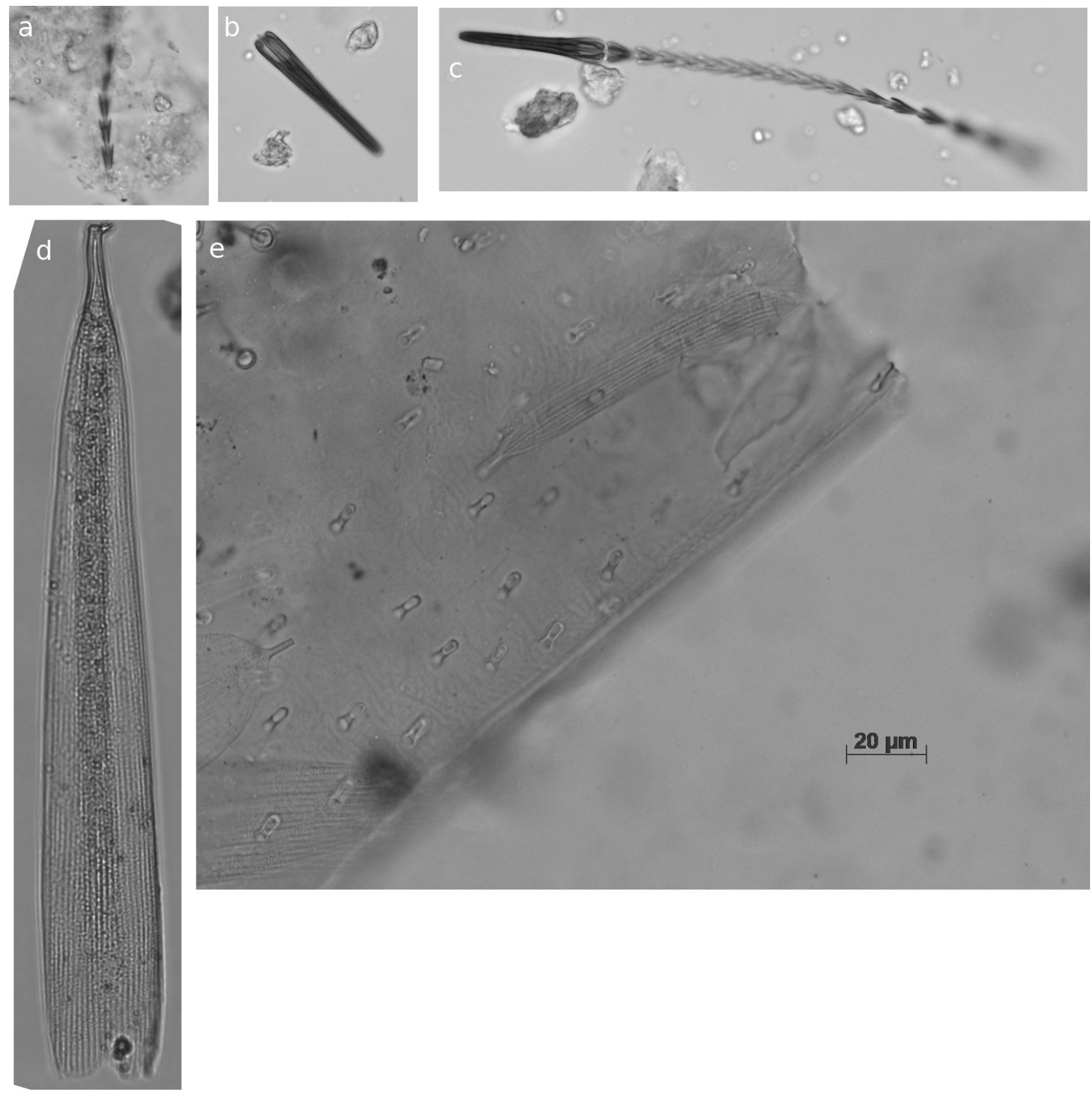

Figure 12.2: Insect parts that are likely the result of post-excavation contamination during storage in the museum. a) Fragment of a hair from a dermestid beetle larva. Unlike feather barbules, the segments are very fine, roughly $5 \mu \mathrm{m}$. b) Fragment of the end of a hair from a dermestid beetle larva. c) More complete hair from a dermestid beetle larva. d) Large wing scale from a member of the Lepidoptera (moths and butterflies). e) Section of the wing of a member of the Lepidoptera, with the attachment marks for the (mostly missing) wing scales in focus. Two folded scales are visible, one center top and the other lower left. The scale bar in this sub-figure applies to the entire image. 


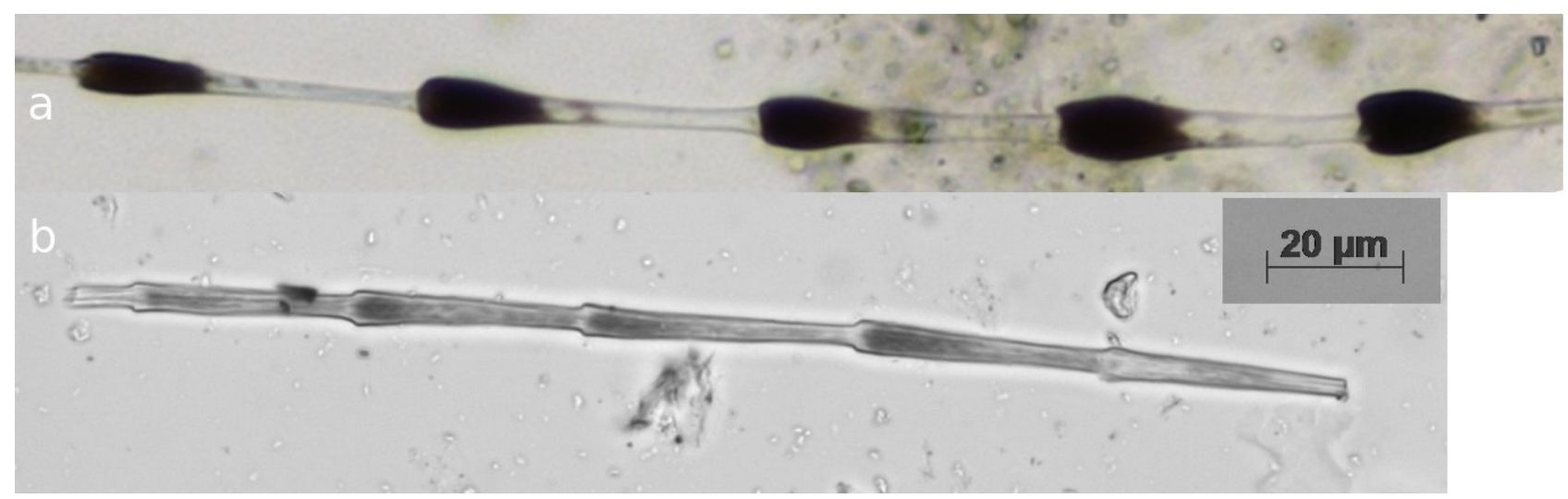

Figure 12.3: Feather barbules. These two barbules were recovered from human dental calculus. The scale bar applies to both sub-figures.

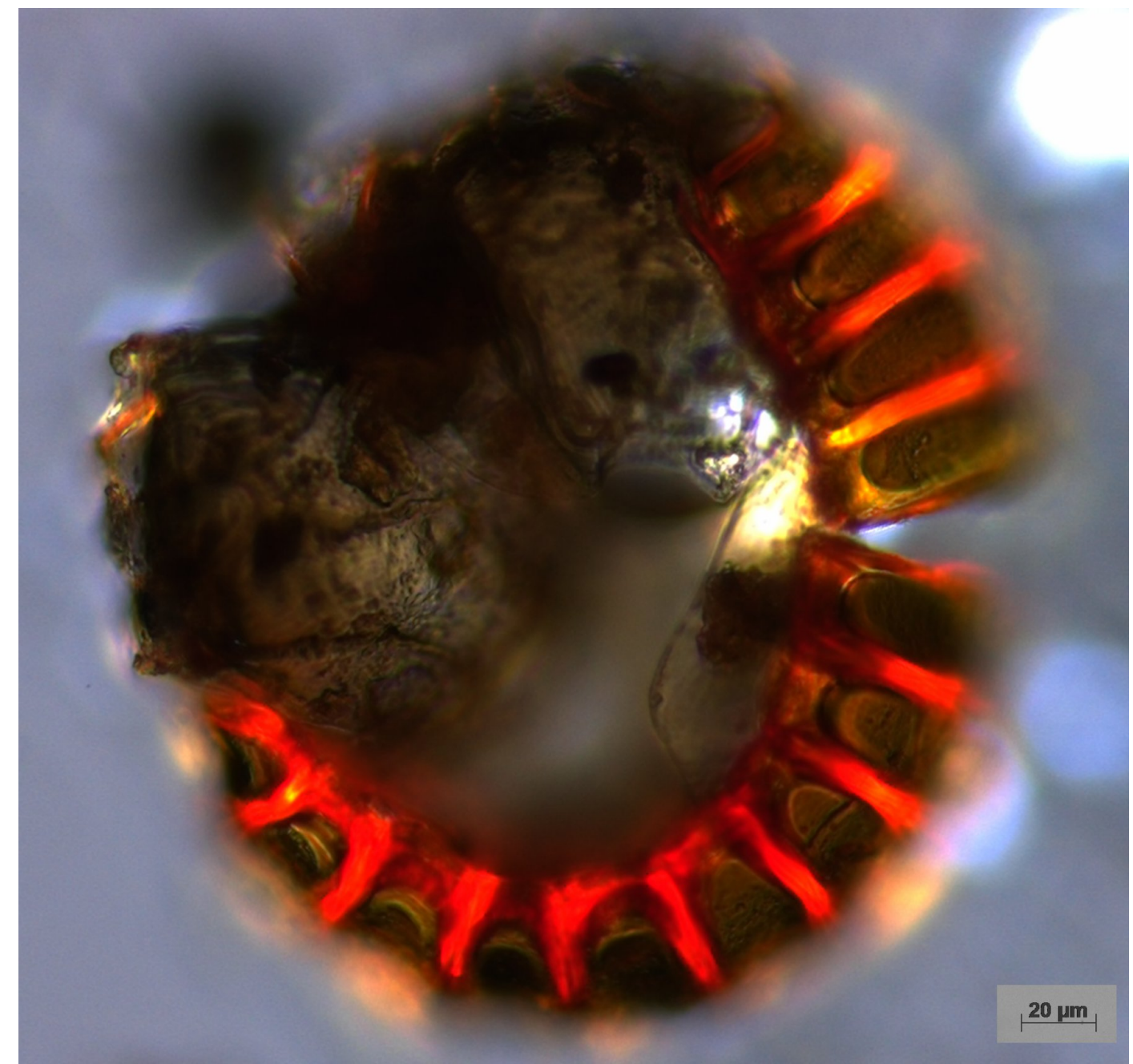

Figure 12.4: Fern Sporangium. This sporangium was found in a modern sediment sample. 


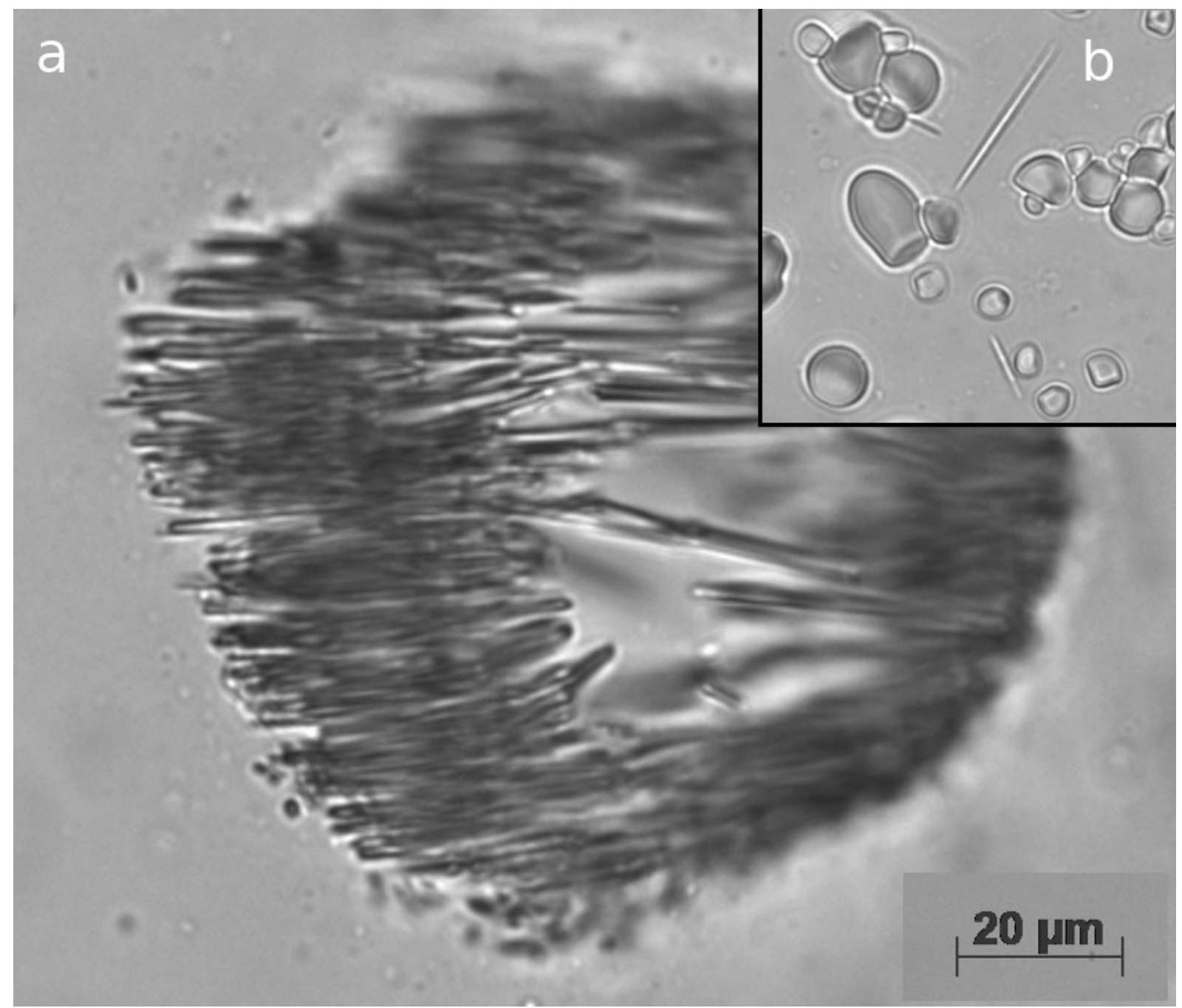

Figure 12.5: Raphides. The long, needle-like calcium oxalate crystals found in some taxa. Both of these examples come from modern reference material. a) a large ring-shaped cluster of raphides from a member of the Vitaceae. b) starch and isolated raphides found in Arum maculatum. The scale bar in the lower right applies to both sub-figures. 